\title{
気象モデルWRFを用いた湖上風の再現 と波浪推算 \\ NUMERICAL ESTIMATION OF WIND AND WAVE FIELDS FOR LAKE ENVIRONMENT USING MESO-SCALE ATMOSPHERIC MODEL WRF
}

\author{
新谷 哲也 ${ }^{1}$ \\ Tetsuya SHINTANI
}

1 正会員 博士（工）首都大学東京 助教 都市環境学部都市基盤環境コース

（干192-0397 東京都八王子市南大沢1-1）

\begin{abstract}
Wind and wave fields are computed for the Lake Kasumigaura using numerical atmospheric and wave models. The meso-scale atmospheric model WRF is employed for predicting the wind field over the surface, while the temporal and spatial wave fields are computed by the third-generation wave model SWAN using the output of WRF. The computed results are compared with the observed wind and wave data. The compared periods are chosen during the passing of the typhoons 200704 and 200709. WRF reproduces the observed wind speed and direction quite well at two observation points inside the lake except the peak of typhoon wind. Consequently, the predicted significant wave height and period become smaller than the observed data near the wind peak. The wind field forecasting is also performed using the forecasting meteorological data (GFS). The results show the availability of the present model for forecasting the wind fields over the lake.
\end{abstract}

Key Words : meso-scale atmospheric model, wave model, wind wave, lake

\section{1. はじめに}

湖沼や貯水池において流動を引き起こす主要因の一つ は水面に作用寸る風応力である.このため，湖上の風速 場を適切に予測・再現することが，水域内の諸現象（流 動，波動，混合・連行等）を解明するための重要なポイ ントとなっている。一般に湖上風の情報は観測によって 得られてきているが，そのデータを利用する上で幾つか の問題点がある，例えば，風の測定は湖面ではなく，近 接する地上での気象計の值を利用することが多いこと， 気象計を複数地点に設置して風の空間分布を考慮するこ とはまれで，一点で計測された風速を湖面一様風として 扱うこと等が挙げられる.

一方，湖内の流れ・波等の諸現象に関する理解は数值 計算手法の進歩に伴って非常に深まり，比較的大きなス ケール（水域スケール）の現象は徐々に明らかになって いる. しかしながら，近年重要視されている水質や生態 系の変化は局所的に生じており，これらの現象をより詳 細に検討寸るためには，局所的な流動・波浪現象を的確 に再現できる必要がある。このため，上記のような，風 の空間分布を考慮しない流動・波浪現象の再現・予測手
法には限界が来つつある．鶴田・石川 ${ }^{11)}$ は，この点に着 目して, 小川原湖における風速分布の現地観測を行い, 風の空間分布が湖流のシミュレーション結果に与える影 響を議論した。 その結果, 湖上風が周辺地形に大きく影 響されること，風の空間分布が湖内流動に大きく影響を 与えることを示した. 鶴田・石川11) も述べているように, これらの問題を解決するためには，数值気象モデルを用 いるか，広範囲にわたって現地観測を行うかが，現在実 行可能な解決方法である.

近年では気象客観データやメソスケール数值気象モデ ルがインターネットを通じてダウンロード可能であり， 比較的容易に利用できるようになっている，また，市販 の一般的なパーソナルコンピューターを用いて，短期間 もしくは比較的低解像であれば，十分に実用に耐えうる 計算ができる，例えば，土木の分野においても，海上で の台風時の波浪推算や流動解析（森 $5^{2)}$ ，小林 ${ }^{3)}$ ，村上 $ら^{4)}$ ) などに利用され始めている. 数值モデルの利点と しては, 現地観測に比べて, 空間解像度の高い風速場を 推定することができることに加えて，過去に観測データ のない期間・場所においても過去の客観データを用いて 気象再現計算が可能なこと，予測客観気象データを用い 
た気象予測が可能であることが挙げられる.これらの観 点から, 数值気象モデルは, 湖沼・貯水池において風に 励起される諸現象を解明するための非常に強力なツール となりうることが予想される。 しかしながら，現在まで 湖沼や貯水池などの比較的小規模な水域における諸現象 の再現を目的として, 数值気象モデルの適用性を議論し た研究はあまり見受けられない.

そこで本論文では, メソスケール数值気象モデルの湖 上風の再現・予測に関する適用性を確認することを目的 として研究を行った. 対象水域は, 茨城県の南部に位置 する霞ケ浦とし, 計算された風速場を実測值と比較する とともに, 計算グリッドの解像度, 初期・境界条件の計 算結果一の影響を確認する。 また，本研究の延長線上に は, 湖内に流入・発生する濁りの挙動予測を考えている ため，底泥の巻き上げ現象(例えば，梅田ら ${ }^{5}$ ，豊田ら ${ }^{6)}$ ) に対して重要となる波浪の再現を試み, こちらに関して も実測データと比較し，検討を行った.

\section{2. 数値モデルについて}

本研究では，2007年に日本に上陸した台風0704号 (MAN-YI) 襲来時 (7/10〜7/20) における湖上風と波浪の 再現性の確認, 及び台風0709号(FITOW) 襲来時 (9/4〜 9/9) における風速場の予報精度の検証を試みた. 計算対 象とした霞ヶ浦は，水域面積 $220 \mathrm{~km}^{2}$, 東西方向約 $40 \mathrm{~km}$ で最大水深7.1m (平均水深約 $4 \mathrm{~m})$ の浅い湖である (図-1). 周辺地形は比較的平坦であるため, 周辺に複雑地形を有 し，より気象変動が複雑になると予想される貯水池等一 の適用性を検討する前段階の研究対象として適した湖と いえる.

\section{(1) メソスケール気象モデル}

現在，局所気象を再現するためにメソスケールの気象 モデルが用いられはじめ，工学的な目的に対しても活発 に用いられ始めている. 米国を中心とした様々な大学・ 研究機関がモデル開発を精力的に行っており，その中で もモデルのソースコードが公開されているメソスケール 気像モデル, MM5 (Fifth-Generation NCAR / Penn State Mesoscale Model), WRF (Weather Research and Forecasting), RAMS (Regional Atmospheric Modeling System)が比較的容 易に利用できる.この中でMM5は，歴史も古く情報と研 究例が最も多い. 本研究では, 間瀬ら゙) と同様に, MM5 の後継として最近期待されている非静水圧・完全圧縮モ デルであるWRF(ARW : Advanced Research WRF)を用い て気象計算を行った.このモデルは, 3次精度のルンゲ・ クッタスキームや 5 次精度の風上差分など高精度な計算 スキームを採用している.

数值気象モデルを実行するに当たって，まず必要とな
ることは，初期条件と境界条件となる客観気象データを 用意することである. 本研究では, NCEP (National Centers for Environmental Prediction) で公開されている GFS-FNL(ファイナルアナリシスデータ)と気象庁メソス ケール客観気象データ(GPV-MSM)の2種類を用いて再現 計算を行った. GFS-FNLは空間解像度が1度, 鉛直27層 の全球データであり,6時間間隔でデータが用意されてい る. 一方, GPV-MSMは, 領域が日本周辺に限定される が，空間解像度が $10 \mathrm{~km}$ ，鉛直17層，3時間間隔でデータ が提供されている. また, 地形と土地利用 (粗度) の情 報については，30秒間隔で与えられているデータを用い ている.これらのデータは, すべてインターネットから 入手可能である. 限られた計算資源で対象領域（霞ヶ浦 周辺）の風の空間解像度を上げるためにネスティング (2way)を用いた。水平空間解像度の影響を確認するため に計算領域の離散化は2パターン, Case-1 (低解像度), Case-2（高解像度）を用意した（図-2）. Case-2におい ては, 高解像度化による計算負荷の増加を考慮してネス 卜数を減らして $(3 \rightarrow 2)$ 計算を行った. また, 計算条件の 詳細を表-1に示した. 計算時間は本研究で用いた計算機 (CPU : Intel Core2Duo 2.33GHz, Memory : 2GB) で両ケー スとも10日間の計算で約2日を要した.

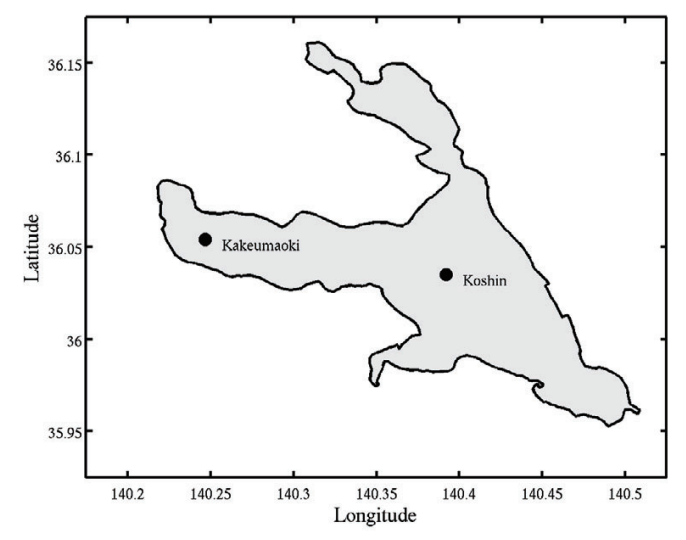

図-1＼cjkstart霞ヶ浦の概略と観測点

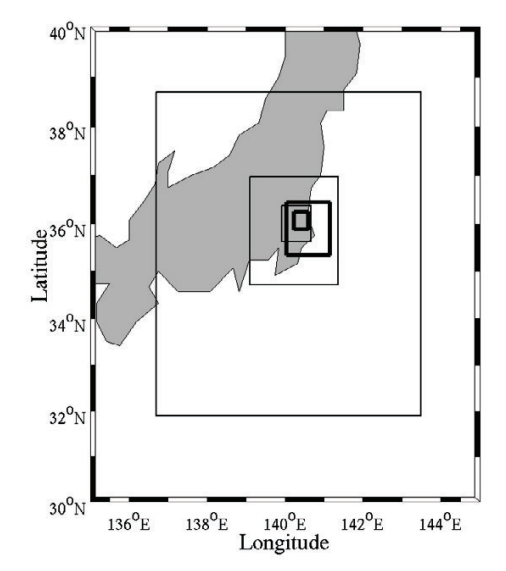

図-2 計算領域（細線: Case-1, 太線 : Case-2) 
表- 1 計算条件（気象モデル）

\begin{tabular}{|l|c|c|}
\hline & Case-1 & Case-2 \\
\hline 初期・境界条件 & \multicolumn{2}{|c|}{ GFS-FNL, GPV-MSM } \\
\hline 標高・土地利用 & \multicolumn{2}{|c|}{ GTOPO30 (30秒メッシュ) } \\
\hline プロジェクション & \multicolumn{2}{|c|}{ Mercator } \\
\hline ネスト数 & 3 & 2 \\
\hline グリッド数 (東西) & $50,58,70$ & 51,49 \\
\hline グリッド数 (南北) & $50,61,73$ & 51,49 \\
\hline 鉛直層数 & \multicolumn{2}{|c|}{28} \\
\hline グリッド閣隔 $(\mathrm{km})$ & $15,5,1.6$ & $2.4,0.8$ \\
\hline 時間間隔 (秒) & $120,40,13$ & 15,5 \\
\hline
\end{tabular}

また，本解析ではシミュレーション結果を客観解析結 果に強制的に近づける 4 次元同化手法は用いていない. 風速場の計算出力は1時間毎とし, Netcdf形式で出力され るデータをMatlabを用いて処理，可視化を行った.

\section{(2) 数值波浪推算モデル}

数值的手法による波浪推算は, 波成分間の非線形作用 の取り扱い方によって, 第 1 世代から第 3 世代一と発展 し，より精度の高い予測が可能となってきている．特に 第 3 世代波浪推算モデルであるWAM, WAVEWATCH III, SWANは, プログラムのソースコードが公開されており, 海洋・海岸を中心として実用的なツールとして利用され はじめている（例えば，間瀬ら ${ }^{8)}$ ，新谷ら $\left.{ }^{99}\right)$ ．湖を対象 とした研究としては, 山口ら ${ }^{10)}$ がエリー湖において WAMを用いて波浪推算を行い，モデルの検証を精密に 行っている.

本研究では，波浪の予測にDelft工科大学で開発された 第3 世代波浪推算モデル SWAN(Simulating WAves Nearshore: Ver. 40.41)を用いた. SWANは，浅水変形も考 慮しているため海洋スケールの波動場から, 実験室スケ 一ルの波動場（水谷ら ${ }^{11)}$ ) までを計算できるモデルであ り, 波作用量(wave action)の平衡方程式を数值的に解くこ とによって波浪を予測する，波作用量スペクトルは，相 対周波数と方向を分割することで離散化され，本研究で は, 周波数分解能は 0.05 から $1 \mathrm{~Hz}$ までを 34 分割, 方向分解 能は360度を24分割とした. また, 空間格子幅は, 約330m とし, 湖底地形 (水深) は国土地理院1/25000の地図から 読み取った值を用いた。モデルの詳細については, Holthuijesen ${ }^{12)}$ によるSWANユーザーマニュアルを参 照されたい. WRFの計算結果から得られる高度 $10 \mathrm{~m} の$ 風 速場をSWANへの入力とした，今回の解析では，波浪が 大気の流動に与える影響を考慮しなかった。つまり，波 浪を計算する際, 風応力を一方的な外力として水域に与 えた。

\section{3. 風速場の再現}

本節では，現地観測データを用いて計算された風速場 の再現性検証を行う。観測データには，国土交通省関東 地方整備局霞ケ浦河川事務所から提供された気象観測デ ータを用いた．同事務所のホームページ上には，霞ヶ浦 周辺における風速や波浪のデータ（リアルタイム情報） が公開されている.

図-3，4 亿湖心（緯度 : 36.0378, 経度 : 140.4042）と 掛馬沖（緯度 : 36.0542, 経度 : 140.2467）における風向・ 風速の比較結果を示す (位置は図-1参照)。まず，図一 3は，初期・境界值にGFS-FNLを用いて計算した場合の 風向・風速の比較結果を示している．比較を行った期間 は, 台風襲来前後の10日間とし, 日付はUTC（協定世界 時, 日本標準時と 9 時間差) を用いて示している. 図中 ×印でプロットしたものが観測值 (1時間間隔)を示し， 破線がCase-1の領域を用いて計算した場合の結果，実線 で示した值がCase-2の領域を用いて計算した場合の結果 をそれぞれ示している. 風向に関しては, 北を 0 度とし， 時計回りに角度をとっている（観測值は 16 分割の方位 角で与えられている)。

まず，湖心の風速の結果（図-3 (a)）を考察する．比 較期間における実測データ（×印）の変動を見ると, 7/15 の12:00ごろに風速の最大值（約 $15 \mathrm{~m} / \mathrm{s} ）$ が訪れているこ とがわかる. その他の期間では, 風速が約 $4 \sim 6 \mathrm{~m} / \mathrm{s}$ の風が 卓越していること, また, 気象の日周運動と思われる小 さなピークが点在することがわかる，次に計算結果を見 ると，まず空間解像度の低いCase-1では，風速の時間変 動はある程度類似しているものの, 全体的に観測值に比 ベて風速が小さい值を示していることがわかる，一方， Case-1に比べて解像度の高いCase-2では, 風速が最大值 を迎える期間で，完全にはピーク值を再現できていない が，その他の期間ではほぼ良好に風速を再現しているこ とがわかる. 一方, 下段に示した風向に関しては，風速 の小さい期間（7/12〜 7/13）で一部大きなずれを生じて いる箇所もあるが，両計算結果とも観測值とほぼ一致し ており, 風向に関しては水平空間解像度にそれほど影響 されず，精度良く計算されていることがわかる.

次に，図-3 (b)に示寸掛馬沖における観測結果を見る と, 湖心に比べて全体的に風速が若干小さくなっている ことがわかる.この風速低下を含めた変動傾向は, 完全 ではないが，Case-2の計算結果で再現されている，風速 の最大值における再現性は湖心の場合よりもやや向上し ている. 下段に示した風向に関しては，やはりCase-2の 方が一致は良好であるが，両ケースに大きな差はない． 以上のGFS-FNLを用いた計算結果からは，風速場の予測 
(a)
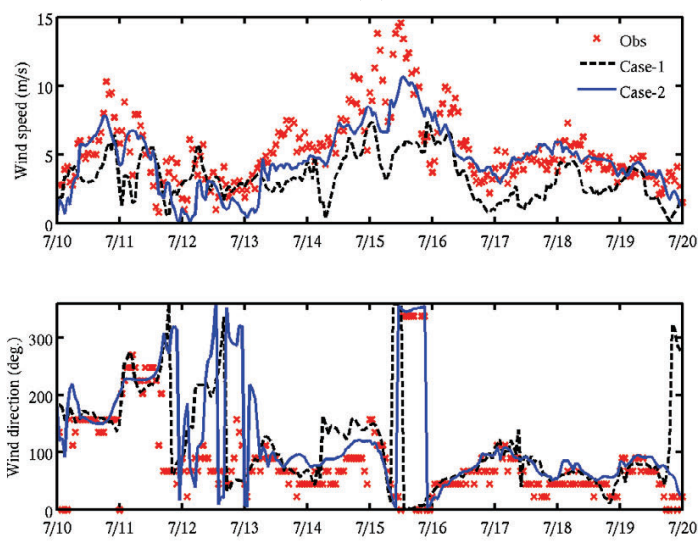

(b)
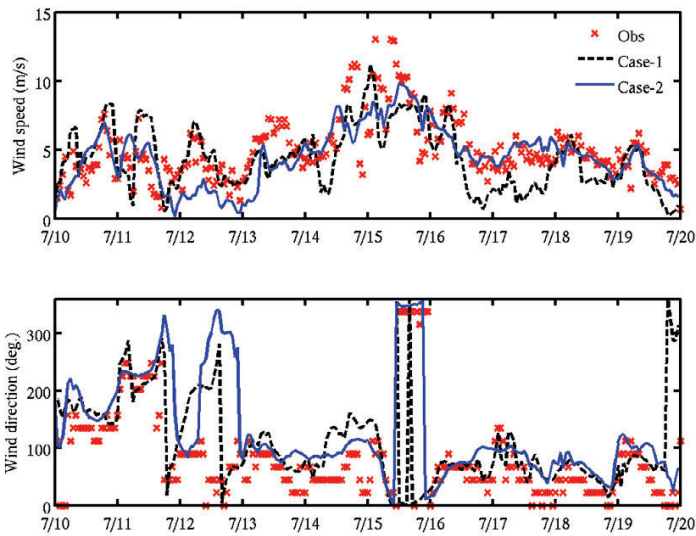

図-3 GFS-FNLを用いた風向・風速の計算結果と実測值と の比較（a）湖心における風速（上）・風向（下）, （b）掛馬沖における風速（上）・風向（下）

に関して，風向は比較的低解像度でも再現性は低下しな いが，風速は解像度に大きく影響をうけるということが 確認された．また，比較的風速が小さく変化の穏やかな 期間(7/17〜 7/20)の再現性が良好であったことから，平常 時の気象がGFS-FNLとWRFの組み合わせで適切に再現 できる可能性は高い. 図-4にGPV-MSMを用いた類似の 結果比較を示す．解像度の低いCase-1では，湖心および 掛馬沖における風向・風速ともに図-3に示した GFS-FNLを用いた結果とほぼ同程度の再現性を示した. しかしながら，GPV-MSMを用いて解像度を上げたCase-2 では，風速の再現性にあまり向上がみられない結果とな った. この理由として，今回の計算から考えられること は，初期・境界条件で与えられる鉛直層の数がGFS-FNL と比較して少ないことが考えられる．また，初期・境界 条件の水平解像度の高いGPV-MSMでは，計算時に水平 解像度をあげても計算結果に与える影響が少ない可能性 もある．この部分は，鉛直解像度の影響も含めてさらに 細かく議論を詰めていく必要がある.

以上のように，本研究で計算を行った中では，Case-2 の空間離散化で初期境界条件にGFS-FNLを用いたケー (a)
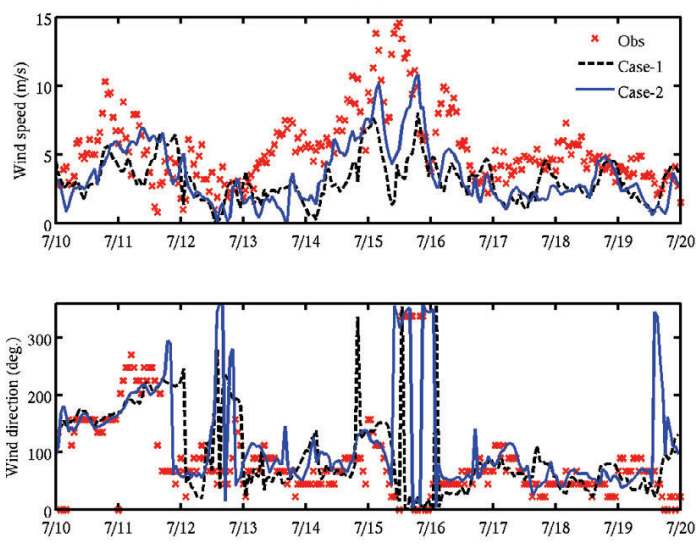

(b)
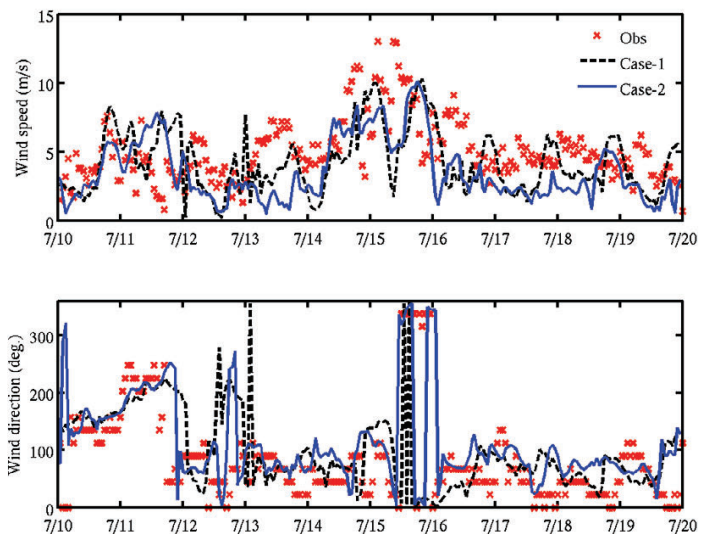

図-4 GPV-MSMを用いた風向・風速の計算結果と実測値との比 較（a）湖心における風速（上）・風向（下），(b) 掛馬 沖における風速（上）・風向（下）

スがもつとも観測地に近いという結果が得られた。 そこ で，このデータをもとに霞ヶ浦における湖上の空間分布 について簡単に考察する. 図-5には, 湖心における風速 の大きさを基準に3つの瞬間における風の空間分布 (高度 10m）を選んで示した．図中，(a)は，風速が比較的弱い 瞬間（湖上最大 $3 \sim 4 \mathrm{~m} / \mathrm{s}$ 程度， $7 / 12$ 12:00)，(b)は，風速 が最大值を示した瞬間 (湖上最大 $10 \mathrm{~m} / \mathrm{s}$ 以上, 7/1512:00), (c)は, 風速が中程度 (湖上最大 $6 \sim 7 \mathrm{~m} / \mathrm{s}$ 程度, $7 / 1800: 00$ ) の空間分布を示している. (a)に示した分布には, 風速, 風向ともに空間変化があり，湖上における波浪や流動の 場所的な違いが顕著になると予想される. (b)に示した強 風時の結果は, 強、気圧勾配のためか, 風速・風向とも にほぼ領域内で一様な傾向が見られる. (c)に示した分布 は，風向はほぼ計算領域で一様であるが，湖上において 陸地部分よりも顕著に風速が大きいことがわかる。この ような場合は，陸上での観測データを用いると湖上風を 低く見積もることとなる，これらのことから，周辺に大 きな起伏を持たない霞ヶ浦であっても，風の空間分布を 考慮した方が，より正確な流動や波浪予測が期待できる ことが予想される. 
(a)

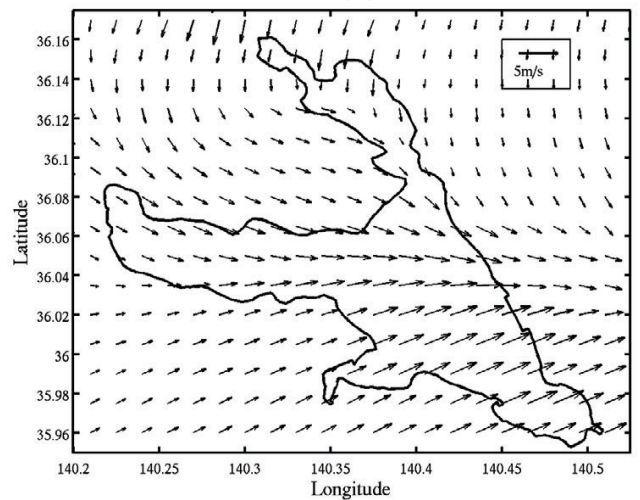

(b)

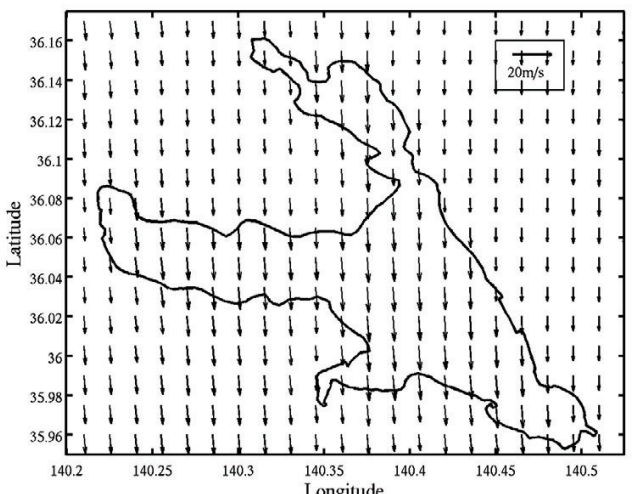

(c)

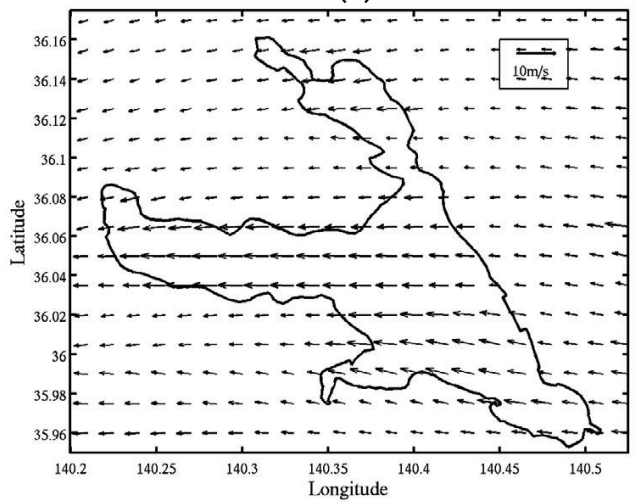

図-5 湖上風（地上 $10 \mathrm{~m}$ ）の空間分布 (a) $7 / 1212: 00 ，(b)$ $7 / 1512: 00$, (c) $7 / 1800: 00$

\section{4. 波浪場の再現}

この節では，WRF (GFS-FNL，Case-2)を用いて計算され た風速場を用いて波浪推算を行った結果を考察する. 図一 6 (a)，(b)，(c)には，それぞれ湖心における有義波高， 掛馬沖における有義波高，湖心における有義周期の比較 を示している. 図中には，観測值 (X印)，WRFの風速場 を与えた推算結果（実線:WRF+SWAN），湖心における実測 風速を空間一様風として与えた推算結果（破 線:OBS+SWAN）が示してある.（a)に示す湖心での有義波 高に関して, WRF+SWANの結果は, 台風による風速のピー ク時付近で再現性が低下しており，計算値は実測值の約 半分程度の波高しか示していない. このズレは, WRFの台 風風速のピーク時付近の再現性低下の影響を強く受けた (a)

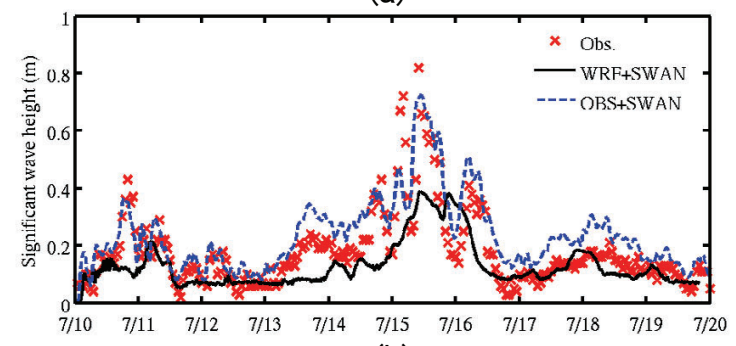

(b)

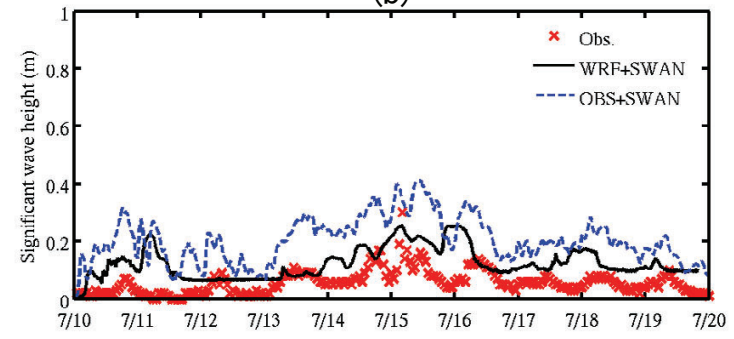

(c)

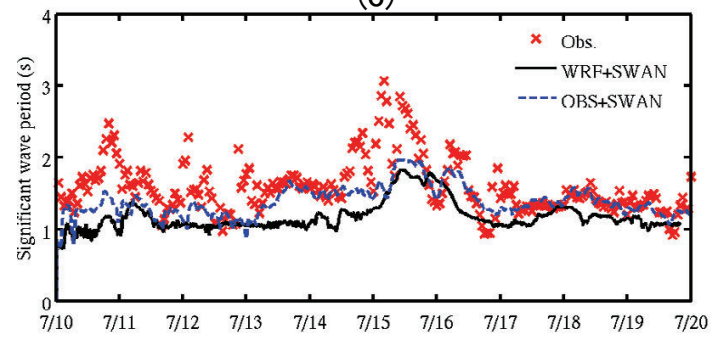

図-6 波浪の観測結果と計算結果の比較 (a) 湖心における有 義波高，（b）掛馬沖における有義波高，（c）湖心にお ける有義周期

結果であると予想される，これに対して，OBS+SWANの結 果は，ピーク時においても，かなり観測された波高を良 好に再現できていることがわかる. 次に，(b)に示寸掛馬 沖における結果を考察する. 掛馬沖は，入り江の奥側に 存在するため, 風速が同程度でも, 吹送距離が短くなる ため波浪が湖心ほど発達しないことが予想される．実測 值では湖心における波高よりもかなり小さな值を示して いるが，WRF+SWAN，OBS+SWANともに予測した結果が実測 值よりも常に大きな值を示している. 特に, 一様風を与 えたOBS+SWANでの結果は, その傾向が強い. (c)に示寸湖 心における有義周期の変化では, 両計算結果間の差は小 さく, 実測值と比較すると全体的に周期が小さく見積も られ, その傾向は風速ピーク時に特に顕著に表れている.

\section{5. 予報客観データによる風速場予測}

最後に，NCEPが発信している予報データ (GFS，空間解 像度1度，3時間間隔)を用いた風速場の予測精度の検証 を行う。予測対象は，事前に予報デー夕を取得すること ができた2007年9月初旬に関東を直撃した台風0709号と した．予報客観データは台風が上陸する前の $9 / 4$ に 384 時 間（16日間）先までのデータをダウンロードし，初期・ 境界条件として用いて計算を行った．図一7に現地観測 
(a)

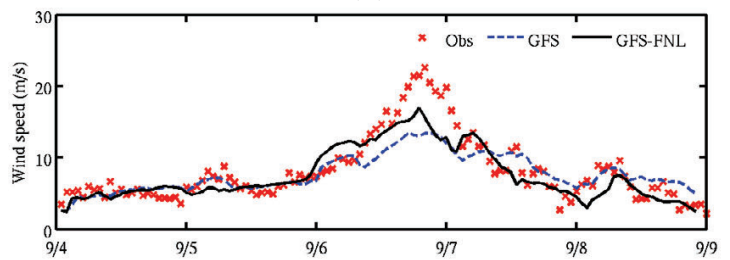

(b)

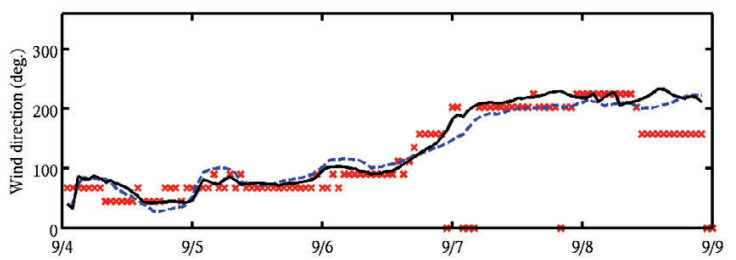

図-7 予報客観データ (GFS) を用いた風速場の計算 湖心にお ける（a）風速，(b) 風向

值（×印）と計算值の比較結果を示した. 図中には，予 測計算結果（破線）の他に，参考のため，前節の再現計 算でも用いた再解析データ (GFS-FNL: 実線)による計算結 果も示した. 台風の接近に伴い, $9 / 7$ 前後に風速が最大值 を示していることが観測值から読み取れる，予報データ による結果は，風速のピーク付近における再現性を除い て十分な予測結果を示しており，風向に関してもほぼ正 確に予測できていることがわかる。一方，事後に発表さ れる再解析データを用いた結果は，風速のピーク部分な じ若干ではあるが，予報值による結果よりも観測值に近 く，改善されていることがわかる．以上のように，予測 值を用いた結果においても，やはり風速のピーク值にお ける再現性が不十分であり，予測風速場を用いた波浪推 算においても，前節に述べたような風速のピーク付近で の有義波高の再現性が問題になると思われる.

\section{6. 結論}

本研究で得られた結論を以下に箇条書きで示す.

（1）メソスケール気象モデルWRFは, 霞ヶ浦の湖上で観 測された風向・風速をほぼ良好に再現できることが わかった。 しかしながら, 台風襲来時に風速がピー クを示寸位相付近において再現性の低下が見られた。

（2）気象再現において，水平空間分解能の影響が風速の 再現性に影響を与えること，風向に関してはその解 像度にあまり影響を受けないことが確認できた。

（3）本解析では，初期・境界条件にNCEPのGFS-FNL を用いたケースが最も再現性が高いという結果が得 られた．計算精度に関しては，さらに水平・鉛直解 像度を上げた計算を行い検証していく必要がある.

（4）波浪推算の結果は，風速ピーク時の有義波高・周期 再現性が低下しており,WRFの風速再現性の影響を
強く受けた.

（5）予報データを用いた風速場の予想は，台風による風 速ピーク時以外は，精度の高いものであった．デー 夕同化手法等を用いてこの期間の精度を上げること によって, 本研究で用いた風速・波浪の予報手段は, 非常に有用なツールとなりうる。

謝辞 : 本研究は, 首都大学東京 傾斜研究費 (若手) によ って行われた. 気象・波浪の現地データは, 国土交通省 関東地方整備局霞ヶ浦河川事務所に提供して頂いた．ま た, 首都大学東京 横山勝英准教授には地形・観測データ に関してアドバイスを頂いた. WRFに関する情報に関して は, 東京工業大学国際開発工学専攻 神田研究室のホーム ページを参考にした。 ここに深甚なる謝意を表する.

\section{参考文献}

1) 鶴田泰士，石川忠晴：小川原湖における風速分布の現地観 測, 水工学論文集, 第43 巻, pp.1043-1048, 1999.

2) 森信人，平口博丸，筒井純一：気象モデルを用いた波浪推 算の高精度化, 海岸工学論文集, 第47巻, 2000.

3）小林智尚, 足立忠行, 水谷英朗, 安田孝志 : 大気 - 波浪 海洋相互結合モデルの構築, 海岸工学論文集, 第48巻, pp.221-225, 2001.

4）村上智一，大澤輝夫，安田孝志：気象場と結合させた湾内 海水流動計算のための多重の座標モデルの開発，海岸工学論 文集，第51巻，366-370, 2004.

5) 梅田信, 長峯知徳, 長広遥, 石川忠晴, 宇田高明 : 霞ヶ浦 湖心部における底泥の巻き上げ過程に関する現地観測および シミュレーション, 水工学論文集, 第45巻, pp.1171-1176, 2001.

6) 豊田政史，北村聡，富所五郎：諏訪湖における風波の影響 を考慮した底泥の輸送解析, 水工学論文集, 第47巻, pp.1213-1218, 2003.

7）間瀬肇, 安田誠宏, 金泰民, 高山知司, 平石哲也, 平山克也： 平成 16 年台風 23 号による室戸市およびすさみ町の高波災害, 京都大学防災研究所年報, 第 48 号, 2005.

8) 間瀬 肇，平尾博樹，國富將嗣，高山知司：SWAN を用い た日本沿岸波浪推算システム構築と適用性の検証，海岸工 学論文集, 第 48 巻, pp.236-240, 2001.

9) 新谷哲也，梅山元彦，小野田祐一：第3世代波浪推算モデル WAVEWATCH III の適用性の検証, 海岸工学論文集, 第52巻, pp.161-165, 2005.

10）山口正隆，畑田佳男，大福学，野中浩一，高見文人：Erie 湖における波浪推算資料の相互比較, 愛媛大学工学ジャ一 ナル, Vol.3, pp.143-154, 2004.

11) 水谷夏樹, OH, Sang Ho, 佐藤裕司, 鈴木武 : 風洞水槽実験 による波浪推算モデル SWAN の検証, 国土技術政策総合研 究所資料, No.90, 2003.

12) Holthuijesen, L.H., Booij, N., Ris, R.C., Haagsma, I.J.G. , Kieftenburg, A.T.M.M. and Kriezi, E.E. : SWAN Cycle III ver 40.11, User manual, 124p., 2000.

(2007.9. 30 受付) 